\title{
Sport Education Model (SEM) Towards Study Result of Passing
}

\author{
Muchamad Ishak \\ Pendidikan Olahraga \\ STKIP Pasundan Cimahi \\ Cimahi, Indonesia \\ muchamadishak11@gmail.com
}

\begin{abstract}
This research is aimed to know the sport education model that significantly influences toward the study result of passing in futsal. The research method used is experimental method. The population was the eleventh grade students of vocational school namely SMK PGRI 1 Cimahi as many as 24 students. All of the population were chosen as sample. The design of this research is pretest posttest control group. The instrument used is passing test that was measured by rubric. Based on the data analysis, it was obtained the value of $t$ as many as 16.58 bigger than $t$ table 1.714 . It can be concluded that learning using sport education model gives significant influence towards the study result in futsal to the students of SMK PGRI 1 Cimahi. Based on the findings, the implication of this research is SEM influences positively towards passing in futsal to the students of SMK PGRI 1 Cimahi.
\end{abstract}

\section{Keywords—Sport education model; passing; futsal}

\section{INTRODUCTION}

Education is an effort to advance children's character, mind and body. Education is an activity in increasing human's personalities by constructing his spiritual body and potencies such as taste, thought, intention, and creation [1]. Physical education basically is an integral part of education system as a whole that aims to develop students' health, fitness, critical thinking, emotional stability, and moral action through physical education activity [2]

Students will obtain various expressions related to pleasurable personalities and creative expression through physical education. Besides, they also have physical fitness, the habit of healthy life and knowledge about humans' movement [3].

Physical education is a process which is conducted consciously and systematically through varieties of activities in order to get an ability, development, intelligence, and character building. The main objection of education is to develop individual to be creative and adaptable to the environment. The nature of physical education is an educational process in employing physical activities to produce holistic changes. Also, the positive influence of physical education is expected to be able to support students' development in cognitive, affective and psychomotor.
Nowadays, futsal tends to be a trendy sport in society. Futsal is easy to be applied since it is almost equal with football. Futsal is simpler than football. Because of its popularity, there is also official competition namely Pro Futsal League (PFL) in Indonesia. Futsal is usually played by five players in each team. Futsal is played as long as $2 \times 20$ minutes. The size of futsal field is $25-45 \mathrm{~m}$ in length and $15-25 \mathrm{~m}$ in width. The size of goal post is $3 \mathrm{~m}$ in length and $2 \mathrm{~m}$ in height. The weight of the ball is $390-430 \mathrm{gr}$.

Futsal is one of sports that use big ball which is played by two teams. Each team is consist of five persons. The aim of this game is the same as football that is entering the ball towards the opponent's goal post [4].

Futsal was created in Montevideo, Uruguay in 1930 by Jua Carlos Ceriani when the world cup held. In Portuguese, this sport was named Futebol De Salao and in Spain was named Futbol Sala. Both of them have the same meaning namely room football [5].

The level of technique mastering determines the result of futsal's competition. It will be impossible if the player only relies on physical ability since the process of playing futsal occurs quickly and there is more touch with the ball. Besides, player needs faster recovery process.

There are some basic techniques in futsal such as passing, stopping, shooting, receiving, chipping, heading and dribbling [6]. Passing is known as key of success in futsal since the players most use this technique most. Passing is an integral component in playing futsal. If the players have good passing, so they are able to play effectively and efficiently.

In general, the dominant technique needed is the player's technique not the keeper because in playing futsal there must be team work in defending and attacking.

Basically, passing in football and futsal is executed using instep foot and also by using top of foot, heel and toe [7]. Passing is a dominant basic technique and is needed in playing futsal. Since the field is so small, so the accurate and tough passing will be needed [8].

Sport education model (SEM) is a new learning model in Indonesia. It has not been applied yet because the teachers 
have less knowledge about this model. SEM applies whole aspects of physical education. On the average, the teachers teach the students without using learning model. SEM is viewed interesting to be implemented in schools.

Sport Education (SE) is curriculum model which was developed by Siedentop in 1994. This model was introduced in Commonwealth Games Conference in Brisbane, Australia [9]. SE is a curriculum and instruction model designed to provide authentic, educationally rich sport exercises for girls and boys in the context of school physical education [10]. On the other word, this model is designed to give obvious exercise to the students about their involvement adjusted to the situation of physical education in school.

This model was studied in Australia, New Zealand, English and Korea. The main objective of SE is to construct the athlete (students) to be competent, literate and enthusiastic.

Competent students mean those who have an ability to participate in good game and be able to perform precise strategy in difficult game. Meanwhile, literate students refer to those who have understanding of rules and the tradition of sport. Also they are able to differentiate which one is bad or good exercise and which one is children's sport or professional sport. The aim of enthusiastic is made in order to make students can participate and take care of the value of sport. Learning using SE is the best way to organize the purpose of physical education by focusing on team work and fair play.

There are some features in conducting SEM [11] such as:

- Content selection. This feature contains choices to choose which sport that will be put in competition and arrange the appropriate scheme.

- Managerial control. This feature takes place in arranging the task and role in competition (coach, manager, etc.)

- Task presentation. It consists of the display of task in order to develop team's skill and strategy.

- Engagement pattern. In this feature the students (outside the team such as linesman, statistician, etc.) are burdened with task and responsibility.

- Instructional interaction. This feature will be visible in students' interaction related to team work in a team and outside the team.

- Task progression. This feature requires the students to form exercise based on their evaluation.

SEM has six identities and each of them is the visualization of real sport management. They are:

- Seasons. SEM uses longer seasons or period included exercise periods (before competition, in competition, after competition and grand final).

- Team affiliation. The students become constant member in a same team in whole seasons. This gives them a chance about affective, reaching the aims, team decisions, and experience. A team will contribute strong feeling towards themselves and as team member.

- Formal competition. The students make a lot decisions about the formation and the implementation in a season. They can modify the rule of the game. The schedule of formal competition makes them decide the short term and long term in the season. The schedule will make the player focus on the exercise and the preparation.

- Culminating event. Usually, there are several competition systems: round-robin tournament, team competition or individual competition either one meeting or home away system.

- Record keeping. The competition occurred gives opportunity to take a note as strategy and motivation. A note can be easy or difficult depend on students' talent. By taking note, they help to provide background of competition schedule. The statistic is also able to be used by coach and player to analyze their strength and opponent.

- Festivity. Sport event is popular by its merry. In small scale (without limit the event) students can conduct celebration of champion.

SEM is one of learning models in physical education subject that makes the students active in joining learning process. The students who are involved in SEM will be enthusiast and competent in doing sport. Furthermore, they tend to develop towards good direction and they are able to enhance their fitness.

The students could construct their own motivation since they have responsibility given by the teacher. They will experience joyful sport.

\section{RESEARCH METHOD}

To obtain an appropriate data related to this research, the researcher used experimental method and pretest - posttest control group. Experimental method is used as one way to seek the causal relationship that is intentionally presented by the researcher by eliminating intruding factor [13].

The research needs the data resource. Generally, the data resources are population and sample. Population has important role because population is the entire object of the research. Population in generalized area is consist of object/subject that has certain determined characteristics and qualities that will be studied and concluded.

Sample is a part of examined population. In determining the sample, the researcher must seek those who represent the population.

In this research, the population was the students of SMK PGRI 1 Cimahi that consisted of 758 students. By using cluster sampling technique, as many as 24 students were taken as sample. Cluster sampling technique was chosen since the 
object or the data resource consisted of large number. The research design can be seen in following figure:

\section{$\mathrm{O}_{1} \quad \mathrm{X} \quad \mathrm{O}_{2}$}

Figure 1

Pretest Posttest Control Group Research Design [14]

Note

$\mathrm{O}_{1} \quad$ : Pretest

$\mathrm{X} \quad$ : treatment using SEM

$\mathrm{O}_{2} \quad$ : Posttest

The data was obtained from students' pretest and posttest score in doing test. The score was assessed through rubric. Test is some questions or exercise used to measure skill or intelligence that individual have. Test is an instrument used to obtain objective data about students' study result. In this research, the instrument used is passing test [15]. The scoring system can be seen in following table.

TABLE I. THE POINTS OF SCORING TO THE RESULT OF PASSING IN FUTSAL

\begin{tabular}{|c|c|c|c|c|c|c|}
\hline \multirow{2}{*}{ Stage } & \multirow{2}{*}{ No } & \multirow{2}{*}{ Scoring Criteria } & \multicolumn{4}{|c|}{ Score } \\
\hline & & & 1 & 2 & 3 & 4 \\
\hline \multirow{4}{*}{ Preparation } & 1 & $\begin{array}{l}\text { Feet are widely opened as } \\
\text { shoulder parallel to the ball. }\end{array}$ & & & & \\
\hline & 2 & $\begin{array}{l}\text { The foothold is placed beside the } \\
\text { ball approximately } 10-11 \mathrm{~cm} \text { to } \\
\text { the ball. }\end{array}$ & & & & \\
\hline & 3 & $\begin{array}{l}\text { Kicking foot is lifted behind. The } \\
\text { position of the foot is straight to } \\
\text { the target. }\end{array}$ & & & & \\
\hline & 4 & $\begin{array}{l}\text { The body rather leans forwards. } \\
\text { Both of hands are opened aside } \\
\text { to balance the body. }\end{array}$ & & & & \\
\hline \multirow{5}{*}{ Execution } & 5 & $\begin{array}{l}\text { The kicking foot is swung } \\
\text { forward so the instep touches the } \\
\text { ball. }\end{array}$ & & & & \\
\hline & 6 & $\begin{array}{l}\text { When kicking the ball, the eyes } \\
\text { look at the ball. After kicking the } \\
\text { ball, the eyes look at the ball } \\
\text { route. }\end{array}$ & & & & \\
\hline & 7 & $\begin{array}{l}\text { When kicking the ball, the body } \\
\text { rather leans forwards. }\end{array}$ & & & & \\
\hline & 8 & The hands are aside the body. & & & & \\
\hline & 9 & $\begin{array}{l}\text { Control the dribbling ball } \\
\text { forwards. }\end{array}$ & & & & \\
\hline \multirow{5}{*}{$\begin{array}{l}\text { Follow- } \\
\text { through }\end{array}$} & 10 & $\begin{array}{l}\text { The kicking foot is placed on the } \\
\text { ground. }\end{array}$ & & & & \\
\hline & 11 & Move forwards 2-3 steps. & & & & \\
\hline & 12 & $\begin{array}{l}\text { The eyes still look at the ball and } \\
\text { target. }\end{array}$ & & & & \\
\hline & 13 & $\begin{array}{l}\text { The position of hands is aside the } \\
\text { body. }\end{array}$ & & & & \\
\hline & 14 & The body relaxes. & & & & \\
\hline \multicolumn{3}{|l|}{ Total } & & & & \\
\hline
\end{tabular}

Skill can be described as an indicator to mastering level in something. Skill points to particular action. Many activities are considered to skill and its mastering degree explains the level of skill. In other word, one or some strengthened movement patterns are skill.

Skill is also known as the activity related to nerve which is done physically such as writing, typing, doing sport, etc. Not all of the motoric activities are mentioned as skill, but all of skills are motoric activities.

TABLE II. THE CRITERIA OF SCORING NORM IN MASTERING PASSING IN FUTSAL

\begin{tabular}{|c|c|c|}
\hline $\begin{array}{c}\text { Percent } \\
\text { age }\end{array}$ & $\begin{array}{c}\text { Score } \\
\text { Range }\end{array}$ & Criteria \\
\hline $\begin{array}{c}80- \\
100\end{array}$ & $45-56$ & $\begin{array}{c}\text { Very } \\
\text { good }\end{array}$ \\
\hline $66-79$ & $37-44$ & Good \\
\hline $56-65$ & $31-36$ & Enough \\
\hline $41-55$ & $23-30$ & Bad \\
\hline $0-40$ & $0-22$ & Very bad \\
\hline
\end{tabular}

\section{RESULT}

All of the data are analyzed using statistical test. The researcher collected the data from the result of passing test in futsal. The steps of calculating the data are follows:

- Calculating the mean score

- Calculating the standard deviation

- Substituting the raw data into z score

- Testing the normality

- Testing the homogeneity

- Conducting hypothesis test using t test.

\section{A. Mean Score and Standard Deviation}

The first step that was conducted by the research was arranging the data obtained. Then, the researcher calculated the mean score and the standard deviation. The result can be seen in following table:

TABLE III. THE RESULT OF MEAN SCORE AND STANDARD DEVIATION

\begin{tabular}{|l|l|l|l|}
\hline Group & $\begin{array}{l}\text { Test } \\
\text { period }\end{array}$ & $\begin{array}{l}\text { Mean } \\
\text { score }\end{array}$ & $\begin{array}{l}\text { Standard } \\
\text { deviation }\end{array}$ \\
\hline Group & Pretest & 27.04 & 2.05 \\
\cline { 2 - 4 } SEM & Posttest & 37.5 & 3.09 \\
\hline
\end{tabular}

From the table, it is known that the mean score of pretest is 27.04 and the mean score of posttest is 37.5. Meanwhile, the standard deviation of pretest is 2.05 and the standard deviation of posttest is 3.09

\section{B. Normality Test}

Normality test was conducted using liliefors test approach. The hypothesis is there is no different result from SEM towards the enhancement of passing in futsal to the students of SMK PGRI 1 Cimahi. 
TABLE IV. THE RESULT OF NORMALITY TEST

\begin{tabular}{|c|c|c|c|c|c|}
\hline \multirow{2}{*}{ Group } & \multirow{2}{*}{$\begin{array}{c}\text { Test } \\
\text { period }\end{array}$} & \multirow{2}{*}{ Lo } & \multicolumn{2}{|c|}{ L table } & \multirow{2}{*}{ Result } \\
\cline { 3 - 4 } Group & Pretest & 0.132 & \multicolumn{2}{|c}{0.173} & Normal \\
\cline { 2 - 3 } SEM & Posttest & 0.102 & & Normal \\
\hline
\end{tabular}

Based on the table, the value of Lo from pretest is 0.132 and from posttest is 0.102 . The critical value of $\mathrm{L}$ is 0.173 . Both of Lo are smaller than $\mathrm{L}$ table which means the data from two periods are normal.

\section{Homogeneity Test}

TABLE V. THE RESULT OF HOMOGENEITY TEST

\begin{tabular}{|c|c|c|c|}
\hline Group & F & F table & Result \\
\hline Group SEM & 2.26 & 2.7 & Homogeneous \\
\hline
\end{tabular}

According to the table above the value of derived $\mathrm{F}$ is 2.26 . It is smaller than F table (2.7) which means the data from pretest and posttest are homogeneous.

\section{Hypothesis Test}

This test was conducted in order to know how SEM influences passing in futsal to the students of SMK PGRI 1 Cimahi. The result can be seen in following table:

TABLE VI. THE RESULT OF SIGNIFICANCE TEST

\begin{tabular}{|c|c|c|c|c|c|c|}
\hline \multirow[b]{2}{*}{$\begin{array}{l}\text { Gro } \\
\text { up }\end{array}$} & \multirow[b]{2}{*}{$\begin{array}{c}\text { Test } \\
\text { period }\end{array}$} & \multirow[b]{2}{*}{$\begin{array}{c}\text { Mea } \\
n \\
\text { score }\end{array}$} & \multirow{2}{*}{$\begin{array}{c}\text { Standar } \\
\mathrm{d} \\
\text { deviati } \\
\text { on }\end{array}$} & \multirow[b]{2}{*}{$\mathrm{t}$ test } & $\mathrm{t}$ table & \multirow[b]{2}{*}{ Result } \\
\hline & & & & & $0.05(46)$ & \\
\hline \multirow{2}{*}{$\begin{array}{l}\text { Gro } \\
\text { up } \\
\text { SE } \\
\text { M }\end{array}$} & Pretest & $\begin{array}{c}27.0 \\
4\end{array}$ & 2.05 & \multirow{3}{*}{$\begin{array}{c}16.5 \\
8\end{array}$} & \multirow{3}{*}{2.021} & \multirow{3}{*}{ Significant } \\
\hline & $\begin{array}{c}\text { Posttes } \\
\mathrm{t}\end{array}$ & $\begin{array}{c}37.5 \\
0 \\
\end{array}$ & 3.9 & & & \\
\hline \multicolumn{2}{|c|}{ Rise } & 4.22 & 9.57 & & & \\
\hline
\end{tabular}

The calculation above show the value of $\mathrm{t}$ test from exercise using SEM is bigger than the table $(16.58>2.021)$. So the hypothesis is rejected. It means there is a significant difference in implementing SEM towards study result of passing in futsal to the students of SMK PGRI 1 Cimahi.

\section{DISCUSSION}

According to the result about the study result of passing in futsal, it has good improvement. This is proven by the result of calculation of $\mathrm{t}$ test that is 2.75 which is bigger than $\mathrm{t}$ table 2.021. So, the hypothesis is rejected and the alternative hypothesis is retained stating there is significant influence from the implementation of SEM towards the study result of passing in futsal to the students of SMK PGRI 1 Cimahi.

By using this learning model, the teachers are urged to give learning model based on curriculum. The students have double roles. The first one, the students' role as a team consisted of player, coach or captain. The other one is nonplaying role consisted of linesman, referee, retriever, etc. Those roles are basis in assessment towards students' success in learning.

\section{CONCLUSION}

Based on the research and the data analysis, the researcher draws conclusion that there is significant improvement to the students of SMK PGRI 1 Cimahi after being given SEM as a treatment as long as three weeks towards passing in futsal.

\section{IMPLICATION}

Based on the findings, the implication of this research is SEM influences positively towards passing in futsal to the students of SMK PGRI 1 Cimahi.

\section{SUGGESTION}

According to the result of research, the researcher suggests SEM becomes a reference for the teacher and coach in enhancing students' study result especially in passing in futsal. SEM makes the students easy to remember the movement. To the next researcher, it is better to conduct this learning model to other sport with larger sample.

\section{ACKNOWLEDGMENT}

The researcher gratefully acknowledges the support and generosity of STKIP Pasundan Cimahi. To which without them, the present research could not have been completed especially to Dr. Ahmad Sobarna as the head of Physical Education study program. Also, thanks to Nurjanah and Eli Nugraha for their feedback.

\section{REFERENCES}

[1] Hamdani, Strategi Belajar Mengajar. Bandung: CV Pustaka Setia, 2011.

[2] Rosdiani, Model Pembelajaran Langsung dalam Pendidikan Jasmani dan Kesehatan, Bandung: Alfabeta, 2012.

[3] Rahayu, Strategi Pembelajaran Pendidikan Jasmani. Bandung: Alfabeta, 2013.

[4] Narti, Futsal. Bandung: Indahjaya Adipratama, 2007

[5] Jaya, Futsal: Gaya Hidup, Peraturan dan Tips-Tips Permainan, Yogyakarta: Pustaka Timur, 2008.

[6] Irawan, Teknik Dasar Modern Futsal. Jakarta: Pena Pundi Aksara, 2009.

[7] Asriady, Buku Pintar Panduan Futsal. Jakarta Timur: LaskarAksara, 2014

[8] Susworo, Saryono, and Yudanto, "Basic skill test in playing futsal," JIP Transl.J.Indonesia, vol.11, pp. 144-156, 2009.

[9] D. Siedentop, Sport education: A retrospective., vol. 21., 2002, pp.409418.

[10] Kurniawan, "Penerapan SEM dalam konteks kurikulum," JUPI, in press.

[11] Metzler, Instructional Models for Physical Education. Allyn \& Bacon A Pearson Education Company, 2000.

[12] Arikunto, Prosedur Penelitiian Suatu Pendekatan Praktik. Bandung: Rineka Cipta, 2010.

[13] Sugiyono, Metode Penelitian Kuantitatif dan R\&D. Bandung: Alfabeta, 2012.

[14] Nurhasan, Tes dan Pengukuran dalam Pendidikan Jasmani. Cimahi: STKIP Pasundan, 2013. 